\title{
Return Migration and Occupational Change: The Case of Pakistani Migrants Returned from the Middle East
}

\begin{abstract}
G. M. ARIF and M. IRFAN
This paper examines the factors affecting occupational composition of Pakistani workers upon their return from Middle East employment by using the 1986 ILO/ARTEP Survey of Return Migrant Households. In view of the concentration of workers in lowstatus occupations prior to migration, there was a great incentive for them to change these occupations after return. The study shows that the economic resources gained from overseas employment gave migrants the strength to seek independent employment, and there was a clear move out of the production-service occupations into business and agriculture occupations. This movement was strongly related to migrants' length of stay in the Middle East. Since the occupational structure of the general population remained almost unchanged in the 1970s and 1980s, the employment trends exhibited by return migrants could largely be attributed to overseas migration. However, the study shows that businesses and farms established by migrant workers were small-scale.
\end{abstract}

\section{INTRODUCTION}

Occupational choice is a developmental process that extends over many years [Weiss (1968); Gill (1989)]. The theory of human capital views occupational choice as an intervening variable associated with maximising lifetime earnings or utility [Boskin (1974); Kossoudji and Cobb-Clark (1996)]. An individual who seeks to maximise his lifetime returns from working might, because of ignorance of abilities, preferences, and working conditions, face uncertainty as to the returns available in various jobs. In choosing among occupations, a potential worker thus weighs the benefits, pecuniary and non-pecuniary returns, and costs. According to Boskin (1974), "the worker will invest in changing occupation only if the returns are significantly large to make the particular change of occupation the most profitable use of his limited resources". Thus mobility occurs if the expected (lifetime) returns to the resources in an alternative occupation exceed those in the current occupation [Shaw (1984)], although it is very difficult for potential migrants to predict their income levels after the return home. While educational attainment, qualification

G. M. Arif and M. Irfan are Research Demographer and Joint Director, respectively, at the Pakistan Institute of Development Economics, Islamabad.

Authors' Note: We are thankful to an anonymous referee of this journal for his/her helpful comments on an earlier version of the paper. 
(training), and parental background are important factors in determining an individual's starting-point (first occupation) in the labour market [Brown et al. (1980)], these factors usually provide little explanation of job movement thereafter [Mayhew and Rosewell (1981)]. The experience of individuals in the labour market, particularly duration of stay in the current occupation, gender, age, social ties, and ethnicity are generally considered the important determinants of occupational change [Greenhalgh and Stewart (1985)].

Migration, internal or international, can also promote occupational mobility. The human capital model of socioeconomic attainment views migration as a form of investment whereby the individual initiates a geographical move with the expectation of drawing net cumulative gains over his working life [Wilson (1985)]. Migrants not only tend to move to higher occupational levels but also experience more upward mobility than non-migrants [Blau and Duncan (1967); Wilson (1985)]. It may be added that a distinction needs to be made between situations where wage gains due to migration are associated with occupational upward mobility, such as from semi-skilled to foreman, and the cases where wage gains may not result in such mobility but may generate the inverse association. In this respect, the Middle East migration phenomenon is peculiar. Under this system, the duration of stay of contract workers is clearly specified and they are expected to return to their home countries at the expiry of their contracts. Because of the temporariness of their movement and relatively short length of stay, contract workers tend to accept lower skilled jobs for higher monetary returns. In view of the workers' willingness to take the lower skilled jobs, there is a possibility of 'de-skilling', a process whereby overseas workers lose previously held skills [Stahl (1982), p. 888; Smart et al. (1986), p. 106]. Arif (1991:15), for example, estimated on the basis of a learning index, using the 1980 Household Survey of Return Migrants, that 27 percent of Pakistani workers accepted lower-ranking jobs in the Middle East than they held before migration. A degree of de-skilling is a likely consequence of such downward mobility.

Bearing in mind the limited skills acquired in the Middle East and the possibility of de-skilling, it appears that the main asset of many migrants has been their accumulated savings remitted home during and following Middle East employment. It is evident from the empirical studies that migration has provided workers with an opportunity to earn, on average, five to eight times more in the Middle East labour market than they could have in similar occupations at home. The majority of workers have also been successful in transferring back home about threequarters of their overseas earnings [Gilani et al. (1981); Addleton (1992)]. To enhance their economic and social status, workers can use their savings to establish farms and businesses upon their return. Indeed, they have the advantage of prior knowledge of the area to which they are returning. The question is whether return migration promotes occupational mobility. 
Pakistan, one of the major labour suppliers to the Middle East, has faced return flow of its workers on a large scale since the mid-1980s. ${ }^{1}$ Before migration, about half of these workers from rural and urban areas alike were engaged in poorly paid, low-status jobs in the production sector [Arif (1995)]. In view of the increased socioeconomic status of migrants, primarily through accumulated savings, it is not difficult to imagine that upon return they may have considered their previous occupations to be beneath their acquired status [Stahl (1982)]. Overseas work experience may be an agent for social change, and migrants may move upon their return towards occupations that provide higher incomes and corresponding social status [Campbell et al. (1974); Thomas-Hope and Nutter (1989)].

With respect to return migration and occupational change, many questions can be raised. For example, was the occupational composition of Pakistani migrants after return from the Middle East different from their pre-migration composition? If it was, what were the directions of occupational flows; and what were the determinants of occupational change? This study investigates these questions. The next section briefly examines the possible motives for Pakistani migrants to change their premigration occupations upon their return. Data sources and methods of analysis are then discussed in Sections 3 and 4. The next section compares the pre-migration occupational composition of return migrants with their post-migration composition. Directions of occupational movements are investigated in Section 6, and the following section examines the experience of other Asian countries. The determinants of occupational change are examined in Section 8, followed by the main findings and the policy implications in the last two sections.

\section{MOTIVES FOR PAKISTANI MIGRANTS TO CHANGE THEIR OCCUPATIONS AFTER RETURN}

Motives for Pakistani migrants to change their occupations upon return from Middle East employment can be understood in the historical context and the traditional job orientations of the country. In Pakistan, the emphasis on one's job varies substantially between rural and urban areas. In rural areas, the possession of land, which is regarded as a symbol of prestige, is one of the major avenues for raising socio-economic status. Land is the pivot of economic, social, and political activity in the rural life of the country, and major economic activities are related directly or indirectly to the agricultural sector [Chaudhry (1980), p. 245]. In rural areas, many occupations, such as weaver, cobbler, carpenter, mason, and blacksmith,

${ }^{1}$ For example, the Sixth Plan (1983-1988) estimated a net emigration of 0.6 million workers during the Plan period, but by the middle of the Plan period Pakistan was faced with net return migration [Government of Pakistan (1988)]. There are some recent signs that return migration has declined. However, if the situation stabilises and out-migration and return migration are equal, or there is positive net migration, Middle East migration will no longer provide a safety valve for the pressures generated by an increasing domestic labour force [Government of Pakistan (1994)]. 
are linked with caste, which determines social status [Lefebvre (1990), p. 77; Khan (1991), p. 230]. Most of these caste-related occupations are generally considered to be of low social status. The principal source of this low status is economic differentiation, mainly in the form of land possession; it lacks other sources of support such as religious and cultural sanctions [Gilani (1986), p. 127]. Existence of the caste system in conjunction with the lack of formal education and training in rural areas restricts occupational mobility [Chaudhry (1980), p. 246; Ballard (1987), p. 36].

In view of the concentration of rural migrants in low-status occupations before migration, there seems to be a great incentive for them to change them upon their return from the Middle East. However, employment opportunities in rural areas are limited, and two primary options are left for return migrants: to buy a piece of land to provide for their livelihood, or to establish a business. Since the mid-1970s, when labour migration to the Middle East first gained momentum, prices of agricultural land have risen considerably. These days it may not be possible for many migrant workers to purchase sufficient agricultural land to provide for the livelihoods of their families. Savings accumulated during overseas employment can, however, provide some migrants with the initial finance to establish small-scale businesses such as retail shops. This would enable them to leave low-status occupations associated with their caste, although it is difficult to overcome the effect of caste entirely and to be socially accepted. Still, Gilani (1986, p. 127) claims, on the basis of his anthropological study of Jaura, a village in Punjab, that "once the economic differentiation was blurred [mainly because of foreign remittances], the hierarchical pattern largely collapsed. The Jaura of today appears to be socially and economically more egalitarian".

The emphasis on jobs in urban areas, where a caste system linked with occupations does not exist, is somewhat different from that in rural areas. The urban population of the country is more educated than its rural counterpart, and general education has from the colonial days been believed to be the passport for entry into Government service. As the 1989 Manpower Commission Report shows, "a whitecollar job at a desk in an important office with some elements of power and patronage is the only goal of the majority of young [urban] persons" [Government of Pakistan (1989), p. 82]. However, these types of jobs are limited in number, and the public sector is incapable of directly absorbing a significant part of the increase in the urban labour force needing jobs [Chaudhry and Chaudhry (1992), p. 806]. As a consequence, the majority of the urban population is engaged in the private sector, primarily as production and service workers [Government of Pakistan (1990), Table 3.4]. In this situation, at the time of returning from overseas, urban migrants also have two choices: first, to seek employment in the private sector; and second, to establish themselves as self-employed workers. Working in the private sector carries with it a constant stigma [Altaf (1983), p. 106]. There is no security and one is considered to be subservient to the boss. The economic resources gained from 
overseas employment can give urban migrants, particularly those who were engaged in poorly paid production sector jobs before migrating, the strength to seek independent employment. The ability of both rural and urban return migrants to establish independent businesses may largely depend on their human capital and on their success in accumulating savings while abroad.

For the analysis of the occupational mobility of Pakistani workers returned from the Middle East, three hypotheses are proposed: (1) that because of low wages and low status, migrants who were production worker before going abroad were likely to choose independent work after return; (2) that the longer the stay of migrants in the Middle East, the easier (because of accumulated savings) it was to establish business after returning home; and (3) that in view of the limited employment opportunities in the formal sector, educated workers were more likely than illiterates to become self-employed after returning home.

\section{DATA SOURCE AND ITS LIMITATIONS}

The 1986 ILO/ARTEP Survey of 1327 Pakistani Return Migrant Households is the main data source. The ILO survey was conducted in three provinces, Punjab, Sindh, and the NWFP, and in Azad Jammu and Kashmir. It was restricted to districts of concentration of migrants [ILO/ARTEP (1987a)]. The selection of the districts was based on information provided by both the 1981 Population Census and the 1986 Airport Survey conducted by the Overseas Pakistanis Foundation. Each selected district was taken as an independent stratum, but in some districts the survey was restricted to those tehsils where a concentration of migrants was indicated by the census and the Airport Survey (Appendix Table 1).

The present analysis identified two problems in the ILO data files during data checking. First, one systematic coding error was found in the original data set. In Sukkur, a district in Sindh province, according to the sample design and the survey fieldwork report, 20 interviews were conducted in three villages [ILO-ARTEP (1987b), Annexure viii]. However, these 20 rural cases had been coded as urban. This error was confirmed in three ways: from the 9-digit processing (or identification) code which was assigned to each household covered in the survey; from the pre-migration occupations of return migrants; and from the list of cities and towns covered during the survey. In the identification code, position 2 indicated rural or urban origin and positions 3 and 4 were fixed for districts. The identification codes for the 20 records from the district of Sukkur showed their origin as rural. The pre-migration occupations of these return migrants revealed that most of them had been engaged in the agriculture sector, which is obviously the predominant source of employment in rural areas only. Similarly, the survey design report did not indicate the name of any city or town in the Sukkur district in which interviews had been conducted (Appendix Table 1). With this strong evidence, the 20 records (households) from the district of Sukkur were recoded as rural for the present study. 
There was another major problem in the ILO data files. The ILO survey contained four sub-modules. Information on the pre-migration socio-economic conditions of migrants and their households and migration-related data were reported in sub-module B, which was administered to all return migrants covered in the survey. Sub-module $\mathrm{C}$ had five different schedules designed to gather information according to the post-migration occupations of the respondents. In general, only one schedule from module $\mathrm{C}$ was administered to each respondent. All sub-modules were processed under different file names. The present analysis thus had to use different data files. One necessary step in data processing was to establish a unique identification which would be used as a key variable in matching records stored on different database files. The 9-digit processing code was used as the identification variable (ID) to match files.

However, matching files was problematic in those households that had more than one return migrant. If a household had more than one returnee, interviewers were advised to fill in a separate set of questionnaires for each one. Since a unique ID was given only to a household, not to an individual record, two or more return migrants within the household were assigned the same ID. For example, in a household with two returnees, who filled in two schedules from sub-module B and two from sub-module $\mathrm{C}$, the four schedules were marked with the same ID. In the absence of any other unique variable, it was not possible to know with absolute certainty which schedule from sub-module $\mathrm{C}$ belonged to which schedule for submodule B. This problem could have been avoided easily if each individual return migrant had been assigned a separate ID. As it was essential for the present analysis to match different data files, those households which had more than one return migrant whose sub-module $C$ could not be matched with his sub-module $B$ were excluded from the analysis. This affected 37 households which reported having more than one return migrant. The exclusion of these 37 households is unfortunate. It obviously eliminates households likely to have done especially well out of labour migration. The final data set consisted of 1251 records. $^{2}$

The ILO data set is 11 years old. Changes occurred in the Middle East migration system during this period might have affected the ILO sample's validity now. For example, the return of 90,000 Pakistani workers mainly from Kuwait during the 1990-91 Gulf war might have changed the composition of return migrants

\footnotetext{
${ }^{2}$ The regional and rural-urban distributions of the ILO sample before and after data cleaning are given in Appendix Table 2, which indicates that about 64 percent of the return migrants were selected from rural areas and about 36 percent from urban areas. Because of the dropping of some cases and the shifting of 20 records in Sindh province from urban to rural areas, this rural-urban distribution is slightly different from the distribution provided in the ILO-ARTEP survey report, which showed a 38 percent urban share of the sample (Appendix Table 2). Similarly, the provincial-regional distribution of the sample changed slightly with the share of the NWFP decreasing from about 22 to 21 percent, while Punjab's share increased from 52 to 53 percent. The proportions of Sindh and AJK in the sample remained almost unchanged.
} 
by country of employment. The ILO sample therefore could be biased, since it did not include returnees from Kuwait. Similarly, it is likely that occupational composition of migrants covered in the ILO survey does not represent those occupations which were being held by Pakistani workers who went abroad during the last decade. But, the mass return of Pakistanis from Kuwait during the Gulf war has not affected the validity of the ILO sample because an overwhelming majority of these workers were re-employed in Kuwait after the war [Hear (1992), pp. 8-10; Stahl and Appleyard (1992), p. 438]. Similarly, occupational composition of Pakistani workers in the Middle East has not changed substantially since the mid1970s. Stahl and Azam (1990, pp. 4-5) show that:

In 1973 some 72 percent of Pakistani workers in the Middle East were classified as production workers, approximately 15 percent were professional/ technical or administrative workers, and fewer than 1 percent were service workers .... With the commencement of infrastructural development in the Middle East in the mid-1970s, however, the composition of demand for Pakistani workers changed markedly. By 1981, ... more than 77 percent of them were engaged in production (mainly construction), professional/ technical or administrative workers accounted for only 4 percent of the annual flow of workers, and service workers accounted for 11 percent. Between 1981-87, ... despite a major shift in the demand for Asian labour generally, the occupational distribution of Pakistanis shifted only marginally.

Moreover, occupational composition of migrants from the ILO sample was fairly similar to the occupational distribution reported by the Bureau of Emigration and Overseas Employment (BEOE) and the Overseas Pakistanis Foundations (OPF) (Table 1). ${ }^{3}$ Seventy-four percent of the respondents in the ILO sample were production workers while abroad and the corresponding figures reported by the BEOE and the OPF were 75 and 73 respectively. Table 1 does show that the share of service workers was slightly greater in the ILO data set than in the BEOE and the OPF data. Even very recent BEOE data did not show any significant change in the occupational composition of Pakistanis in the Middle East: 70 percent of Pakistanis who went abroad during 1994 and 1995 were production workers [Akhtar (1997), p. 2]. Thus, the ILO survey seems to be representative of migrants' occupations in the Middle East. It is worth noting that after this survey no nation-wide study on return migration was conducted.

There is a need to clarify another important point. The ILO/ARTEP survey report, entitled Re-absorption of Return Migrants in the Domestic Economy, was

\footnotetext{
${ }^{3}$ The comparison made in Table 1 is for the period 1980-85, when majority of the respondents covered in the ILO sample went abroad.
} 
Table 1

Occupational Distribution of Pakistani Migrants while in the Middle East, 1980-85

\begin{tabular}{lccc}
\hline $\begin{array}{l}\text { Occupation } \\
\text { while Abroad }\end{array}$ & $\begin{array}{c}\text { BEOE } \\
(1980-85)\end{array}$ & $\begin{array}{c}\text { OPF Registration Data } \\
(1980-85)\end{array}$ & $\begin{array}{c}\text { ILO Sample } \\
(1980-85)\end{array}$ \\
\hline Professional/Technical & 2.9 & 4.5 & 3.5 \\
Clerical & 2.5 & 2.5 & 1.9 \\
Service & 13.9 & 14.3 & 16.7 \\
Agriculture & 3.8 & 3.8 & 1.7 \\
Production Workers & 75.2 & 73.3 & 74.2 \\
Others & 1.7 & 1.6 & 2.0 \\
Total & 100.0 & 100.0 & 100.0 \\
\hline
\end{tabular}

Source: Government of Pakistan (1989); Stahl and Azam (1990); 1986 ILO survey.

based on the 1986 ILO survey, which is also the main data source for this study. ${ }^{4}$ How were the survey data used in that report, and what is distinctive about the use made of the data in this study? The ILO/ARTEP survey report classified return migrants into five major categories: agricultural workers, business workers, regular (permanent) employees, labourers-artisans, and the unemployed [ILO-ARTEP (1987a), p. 5]. Re-adjustment of return migrants in these categories was addressed in five main chapters of the report, one chapter for each category. The above-mentioned classification is a mix of occupations and employment status. The wage employees and labourers-artisans categories are ambiguous because they contain occupations which vary from unskilled labourers to professional workers. The ILO/ARTEP survey report did discuss the pre-migration occupational composition of return migrants while examining their readjustment, but it did not investigate the issue of occupational mobility and its determinants that requires reclassification of postreturn occupations, which is outlined in the next section. In addition, large variations in land productivity and business and job opportunities within the rural and urban sectors suggest that it would be useful to take these variations into consideration when examining the occupational composition of return migrants. The present study is designed to fill these gaps by using the 1986 ILO survey.

\section{METHODS OF ANALYSIS}

The analysis is limited to those return migrants who were employed at the time of the survey and who reported their occupations. In other words, persons who

${ }^{4}$ Although the ILO/ARTEP report consisted of six volumes, the survey data was used in only one volume. Statistical tables were also reported in a separate volume. The other four volumes addressed issues like sample design, estimates of out- and return-migrants and demand for Pakistani workers in the Middle East. 
were not working or were not looking for a job at the time of survey were excluded from the analysis. This restriction was necessary, since these persons did not report their occupations which were needed to examine the occupational mobility. (The post-return employment status of migrants will be explored in a separate paper.) About 15 percent of the ILO sample was unemployed at the time when the survey was conducted, and another 6 percent of the sample was not in the labour force.

The ILO sample is divided into four subcategories: irrigated and non-irrigated areas within the rural sector, and major urban centres, referred to hereafter as MUCs, and remaining urban centres, referred to hereafter as other urban centres (OUCs), within the urban sector. The re-classification of rural areas was based on the percentage of total cultivated area with irrigation facilities in each district, while the classification of urban area was made on the basis of the population sizes of urban centres [for detail on this re-classification, see Arif (1995)]. After reclassification of the sample, the distribution of return migrants by province and region is given in Appendix Table 3. Among 445 urban return migrants, 302 were located in the MUCs and 143 in the OUCs; similarly, out of 806 rural return migrants, 442 lived in nonirrigated areas and the remaining 364 in irrigated areas. This reclassification shows that the ILO sample was widely spread through the four geographical locationsirrigated, non-irrigated, MUCs, and OUCs.

One of the important factors which can affect workers' occupational composition after return, mainly through accumulation of savings, is their duration of stay abroad (hypothesis 2). For the present study, return migrants were grouped, according to their durations of stay, into three categories: short-stayers, mediumstayers, and long-stayers. The 'short-stayers' are those who stayed in the Middle East for a period of two years or less. This category contains those migrants who were relatively unsuccessful in the Middle East labour market in that they were unable to extend their stay abroad beyond a period equivalent to a single contract, ${ }^{5}$ or perhaps even returned before completing the period of one contract. The 'medium-stayers' are those who stayed abroad for more than two years but less than six years. Return migrants who had stayed in the Middle East for six years or longer are designated 'long-stayers'. According to the ILO survey, average duration of stay of workers in the Middle East was 3.6 years and about 36 percent of them were short-stayers (Appendix Table 4). Medium-stayers accounted for 46 percent and long-stayers for 18 percent. On average, urban migrants had stayed longer in the Middle East than their rural counterparts. Within the rural sector, return migrants from non-irrigated areas had stayed longer than migrants from irrigated areas.

In conformity with the Pakistan standard occupational classifications [Government of Pakistan (1984)], the various occupations reported in the ILO survey were divided into eight major occupational groups: professional workers, clerical

\footnotetext{
${ }^{5}$ The period of a contract in the Middle East is usually two years.
} 
workers, service workers, agriculture workers, business workers, skilled workers, unskilled workers, and others. Cross-tabulating pre-migration occupation by postreturn occupation formed an 8 by 8 matrix. However, as noted earlier, occupational data cannot be understood adequately unless one considers the geographical locations of return migrants. As a considerable proportion of cells in the four geographical $^{6}$ sub-matrices were zero, data consolidation was necessary, and the eight occupational categories were reduced to four: professional, agriculture, business, and production workers. The agriculture and business categories are as in the original data set. The professional category included professional and clerical workers, while the production category embraces skilled, unskilled, service, and other workers. Although the mean education of workers combined in one category, for example clerical and professional workers, was not very much different (Table 2 ), the aggregation of occupational categories means loss of some useful information. To avoid this loss, occupations at disaggregated level were also reported for the total sample when pre-migration occupational composition of returnees was compared in the next section with those held during stay abroad and after return.

Table 2

Mean Education (Years) of Returnees by Post-migration Occupation

\begin{tabular}{lcr}
\hline Occupation & Mean Education (Years) & $(\mathrm{N})$ \\
\hline Professional & 12.3 & $(25)$ \\
Clerical & 11.3 & $(20)$ \\
Business & 8.4 & $(318)$ \\
Service & 7.7 & $(91)$ \\
Skilled & 7.3 & $(177)$ \\
Agriculture & 6.9 & $(271)$ \\
Unskilled & 6.6 & $(98)$ \\
Total & 7.8 & $(1000)$ \\
\hline
\end{tabular}

Source: Computed from the 1986 ILO survey data.

Note: Return migrants who were either unemployed or out of the labour force are not included in the table.

One issue related to the occupation categories concerns their rank-ordering. An ordered hierarchy of occupations is considered to be necessary for any discussion of occupational mobility, and mean education is commonly used as the ordering variable [Mullan (1988), pp. 74-75]. However, rank-ordering of occupational categories of return migrants could be misleading. As noted earlier, accumulated savings were the main asset of migrants, and they were likely to use these savings to

${ }^{6}$ Irrigated, non-irrigated, MUCs, and OUCs. 
seek independent work by establishing businesses or purchasing farms. In mobility models, movement of a skilled or service worker to an agricultural occupation will be considered downward mobility, since the ordered hierarchy based on mean education will put the latter at the bottom of the continuum (Table 2).

Even some migrants who were professional and clerical workers before migration might have shifted, because of high monetary returns, to business activities after their return. In view of this complexity, much doubt can be cast upon the validity of mobility models, where specifications would include upward or downward mobility as a dependent variable. Rather, the present analysis proceeds in three phases. The first is a bivariate description of occupational patterns before migration, during migration, and after return controlling for geographical location and duration of stay in the Middle East. Second, occupational outflows are examined to determine which occupations gained or lost workers. Finally, multivariate analysis shows the relative magnitude and importance of the various determinants of occupational change.

\section{OCCUPATIONAL COMPOSITION OF RETURN MIGRANTS: A COMPARISON}

Workers' original (pre-migration) occupational backgrounds compared to their post-migration jobs measure the impact of migration on occupational shifts after migration [Gitmez (1984), p.117]. This comparison is shown in Table 3. To learn more about the occupational shifts over time, occupations held by returnees during their stay in the Middle East are also included in this table. Occupational composition of returnees, without using any aggregation, at the three stages of migration, before migration, during migration, and after return, are presented in Appendix Table 5.

Table 3 shows a concentration of workers in the production-service sector before going to the Middle East. ${ }^{7}$ Approximately two-thirds of the migrants from urban areas and more than half from rural areas were in this sector before migration. In rural areas, 29 percent were engaged in the agriculture sector, while, as expected, the shares of professional-clerical workers were higher among the urban sample than among the rural sample. During migration, production-service sector employment increased substantially: from 60 percent before migration to 91 percent while in the Middle East (Table 3). This indicates a substantial mismatch between the premigration and during-migration occupations of return migrants in the ILO sample. A transition matrix for movement from pre-migration occupations to occupations while in the Middle East shows that about 21 percent of those who were professional workers before migration were production workers in the Middle East (Appendix Table 6). In the case of migrants who were clerical workers before migration, 15

${ }^{7}$ More than half of the production-service sector consisted of unskilled labourers, masons, drivers, carpenters, electricians, tailors, mechanics, and operators (Appendix Table 5). 
Table 3

Percentage Distributions of Return Migrants by Pre-migration and Post-return Occupation, Controlling for Geographical Location

\begin{tabular}{|c|c|c|c|c|c|c|c|c|}
\hline \multirow[b]{2}{*}{ Occupations } & & \multicolumn{3}{|c|}{ Urban Areas } & \multicolumn{3}{|c|}{ Rural Areas } & \multirow[b]{2}{*}{ All Area } \\
\hline & & MUCs & OUCs & Total & Irrigated & Non-irrigated & Total & \\
\hline \multirow[t]{3}{*}{ Professional/Clerical } & (a) & 11.3 & 3.6 & 8.8 & 6.1 & 5.4 & 5.8 & 6.8 \\
\hline & (b) & 10.9 & 10.7 & 10.9 & 3.3 & 2.5 & 2.8 & 5.6 \\
\hline & (c) & 7.9 & 4.5 & 6.7 & 3.6 & 3.1 & 3.3 & 4.5 \\
\hline \multirow[t]{3}{*}{ Agriculture } & (a) & 9.6 & 16.0 & 11.7 & 35.8 & 22.4 & 28.5 & 22.8 \\
\hline & (b) & 2.2 & 0.0 & 1.5 & 2.9 & 0.0 & 1.4 & 1.4 \\
\hline & (c) & 2.6 & 5.4 & 3.5 & 42.8 & 36.3 & 39.3 & 27.1 \\
\hline \multirow[t]{3}{*}{ Business } & (a) & 13.5 & 17.0 & 14.7 & 11.8 & 5.9 & 8.6 & 10.7 \\
\hline & (b) & 3.1 & 0.9 & 2.3 & 2.3 & 0.6 & 1.4 & 1.7 \\
\hline & (c) & 42.4 & 42.0 & 42.3 & 26.1 & 26.6 & 26.4 & 31.8 \\
\hline \multirow[t]{3}{*}{ Production/Service } & (a) & 65.6 & 63.4 & 64.8 & 46.3 & 66.3 & 57.1 & 59.7 \\
\hline & (b) & 83.8 & 88.4 & 85.3 & 91.5 & 96.9 & 94.4 & 91.3 \\
\hline & (c) & 47.1 & 48.1 & 47.5 & 27.5 & 34.0 & 31.0 & 36.6 \\
\hline Total & & 100.0 & 100.0 & 100.0 & 100.0 & 100.0 & 100.0 & 100.0 \\
\hline$(\mathrm{N})$ & & (229) & (112) & (341) & (306) & (353) & (659) & (1000) \\
\hline
\end{tabular}

Source: Computed from the 1986 ILO survey data.

Note: (a) Indicates pre-migration occupational composition of returnees, while (b) shows occupations while abroad, and (c) reveals post-return composition. 
percent were skilled workers and 26 percent were unskilled workers abroad. More than two-thirds of agricultural workers switched to unskilled jobs in the Middle East (Appendix Table 6). In view of this concentration of Pakistani migrants in production work, particularly in unskilled jobs, work experience acquired through Middle East employment might not have enhanced the skill level of many migrants.

After migration, Table 3 shows that production-service sector employment for all migrants declined substantially: from 60 percent before migration and 91 percent during migration to only 37 percent after return. The share of unskilled workers declined from 21 percent before migration and 39 percent while in the Middle East to only 10 percent after return (Appendix Table 5). In turn, business sector employment increased from 32 percent before migration to 60 percent after return. In rural areas, concentration of migrants shifted to agriculture work, while in urban areas the importance of business occupation increased substantially (Table 3).

Table 3 shows that there was no major difference in migrants' pre-migration occupations within urban areas, MUCs, and OUCs. However, within rural areas, irrigated and non-irrigated, there was a substantial variation. For example, more than one-third of return migrants from irrigated areas were engaged in agricultural activities prior to migration compared to about one-fifth from non-irrigated areas. Sixty-six percent of return migrants from non-irrigated rural areas were productionservice workers before migration, while from irrigated areas only 46 percent were in this category. After migration, the differentials prevailing within rural areas largely disappear (Table 3), and in both irrigated and non-irrigated areas, return migrants were concentrated in the agriculture sector.

Table 4 shows distribution of return migrants by pre-migration and post-return occupation, controlling for duration of stay and geographical location. In general, short-stayers, who stayed abroad for less than two years, were concentrated in the production-service sector after return, followed by the agricultural sector, while long-stayers, who stayed abroad for six years or more, were concentrated in the business sector. As the duration of stay abroad rises, there is a distinct decline in the importance of the production-service group and an increase in that of business employment (hypotheses 1 and 2).

For rural migrants, as length of stay abroad rises, there is an increase in business employment, but the agriculture sector remained the dominant category for all durations of stay. For migrants from urban areas, the production-service sector ceased after migration to be the dominant category for long-stayers. It is important to note that for urban migrants who were long-stayers, the production-service sector was the dominant category before migration (Table 4). In urban areas the business category registered the greatest relative increases, from 16 percent before migration to 28 percent after return for short-stayers, 15 percent to 41 percent for mediumstayers and 13 percent to 65 percent for long-stayers. This is in direct agreement with 
Table 4

Percentage Distribution of Return Migrants by Pre-migration Occupation, by Rural-urban Residence, and by Duration of Stay in the Middle East.

\begin{tabular}{|c|c|c|c|c|c|c|}
\hline \multirow[b]{2}{*}{$\begin{array}{l}\text { Pre-migration } \\
\text { Occupation }\end{array}$} & \multicolumn{3}{|c|}{$\begin{array}{l}\text { Pre-migration Composition by } \\
\text { Duration of Stay Abroad }\end{array}$} & \multicolumn{3}{|c|}{$\begin{array}{l}\text { Post-migration Occupation by } \\
\text { Duration of Stay Abroad }\end{array}$} \\
\hline & $\begin{array}{l}\text { Short- } \\
\text { stayers }\end{array}$ & $\begin{array}{c}\text { Medium- } \\
\text { stayers }\end{array}$ & $\begin{array}{l}\text { Long- } \\
\text { stayers }\end{array}$ & $\begin{array}{l}\text { Short- } \\
\text { stayers }\end{array}$ & $\begin{array}{c}\text { Medium- } \\
\text { stayers }\end{array}$ & $\begin{array}{l}\text { Long- } \\
\text { stayers }\end{array}$ \\
\hline \multicolumn{7}{|l|}{ All Urban Areas } \\
\hline Professional/Clerical & 6.0 & 9.5 & 11.1 & 6.0 & 6.5 & 8.3 \\
\hline Agriculture & 12.1 & 7.7 & 11.1 & 6.1 & 2.9 & 1.4 \\
\hline Business & 16.2 & 14.8 & 12.5 & 28.3 & 40.6 & 65.3 \\
\hline Production/Service & 65.7 & 68.0 & 65.3 & 59.6 & 50.0 & 25.0 \\
\hline Total & 100.0 & 100.0 & 100.0 & 100.0 & 100.0 & 100.0 \\
\hline \multicolumn{7}{|c|}{ Major Urban Centres (MUCs) } \\
\hline Professional/Clerical & 5.7 & 12.1 & 19.0 & 7.1 & 7.7 & 9.5 \\
\hline Agriculture & 10.0 & 6.0 & 4.8 & 4.3 & 1.7 & 2.4 \\
\hline Business & 15.7 & 14.7 & 7.1 & 30.0 & 42.7 & 61.9 \\
\hline Production/Service & 68.6 & 67.2 & 69.1 & 58.6 & 47.9 & 26.2 \\
\hline Total & 100.0 & 100.0 & 100.0 & 100.0 & 100.0 & 100.0 \\
\hline \multicolumn{7}{|c|}{ Other Urban Centres (OUCs) } \\
\hline Professional/Clerical & 6.9 & 3.8 & 0.0 & 3.4 & 3.8 & 6.7 \\
\hline Agriculture & 17.2 & 11.3 & 20.0 & 10.3 & 5.7 & 0.0 \\
\hline Business & 17.2 & 15.1 & 20.0 & 24.1 & 35.8 & 70.0 \\
\hline
\end{tabular}


Table 4-(Continued)

\begin{tabular}{|c|c|c|c|c|c|c|}
\hline Production/Service & 58.6 & 69.8 & 60.0 & 62.2 & 54.7 & 23.3 \\
\hline Total & 100.0 & 100.0 & 100.0 & 100.0 & 100.0 & 100.0 \\
\hline \multicolumn{7}{|l|}{ All Rural Areas } \\
\hline Professional/Clerical & 4.7 & 5.6 & 7.1 & 3.0 & 4.5 & 0.9 \\
\hline Agriculture & 28.3 & 25.4 & 27.4 & 39.0 & 35.5 & 49.6 \\
\hline Business & 8.9 & 7.7 & 10.6 & 20.5 & 28.6 & 34.5 \\
\hline Production/Service & 58.1 & 61.3 & 54.9 & 37.5 & 31.4 & 15.0 \\
\hline Total & 100.0 & 100.0 & 100.0 & 100.0 & 100.0 & 100.0 \\
\hline \multicolumn{7}{|l|}{ Irrigated Areas } \\
\hline Professional/Clerical & 5.1 & 6.9 & 5.8 & 4.3 & 4.3 & 0.0 \\
\hline Agriculture & 39.1 & 29.3 & 30.8 & 42.0 & 42.3 & 46.1 \\
\hline Business & 11.6 & 9.5 & 17.3 & 22.5 & 25.0 & 38.5 \\
\hline Production/Service & 44.2 & 54.3 & 46.1 & 31.2 & 28.4 & 15.4 \\
\hline Total & 100.0 & 100.0 & 100.0 & 100.0 & 100.0 & 100.0 \\
\hline \multicolumn{7}{|l|}{ Non-irrigated Areas } \\
\hline Professional/Clerical & 4.2 & 4.7 & 8.2 & 1.7 & 4.7 & 1.6 \\
\hline Agriculture & 15.8 & 22.8 & 24.6 & 35.5 & 31.0 & 52.5 \\
\hline Business & 5.8 & 6.4 & 4.9 & 18.2 & 31.0 & 31.1 \\
\hline Production/Service & 74.2 & 66.1 & 62.3 & 44.6 & 33.3 & 14.8 \\
\hline Total & 100.0 & 100.0 & 100.0 & 100.0 & 100.0 & 100.0 \\
\hline
\end{tabular}

Source: Computed from the 1986 ILO survey data. 
the expectation that a long duration of stay abroad enables migrants and their families to accumulate savings to establish businesses upon permanent return from overseas employment (hypothesis 2). Occupational distributions of return migrants within rural and urban areas, controlling for duration of stay, are also shown in Table 4. There was no major difference within urban areas in terms of changes in occupation. Both the MUCs and the OUCs experienced a clear move out of the production-service sector into the business category. In these two urban sectors the shares of professional-clerical workers also declined.

It is apparent from Table 4 that in the MUCs and the OUCs the productionservice sector ceased to be the dominant category for long-stayers. Within rural areas, irrigated and non-irrigated, length of stay abroad also enabled productionservice workers to shift to business sector, but it showed little effect on agriculture workers. However, Table 4 does show that more than half of long-stayers from the non-irrigated sub-sample were in the agriculture category after return, while the corresponding figure for irrigated areas was about 46 percent. This differential, though not very large, is not in agreement with a priori expectations, since the land in non-irrigated areas is generally less suited to agriculture than the land in irrigated areas. $^{8}$

\section{DIRECTIONS OF OCCUPATIONAL CHANGE}

Table 5 presents transition matrices for movement from pre-migration occupations to occupations after returning from the Middle East. For the total employed sample and the rural and urban sub-samples, there were high percentages on the main diagonals, indicating considerable immobility. Over one-third of migrants in each occupational category were in the same category after migration as before migration. However, there were marked differences in immobility. For example, for the total employed sample, three-quarters of those who were in the business category before migration remained in business upon returning from abroad. A slightly lower proportion (68 percent) of those who had agriculture as their occupation before migration retained it after migration. However, only 41 percent of

\footnotetext{
${ }^{8}$ Several explanations can be offered in this respect. There is a possibility that because of the inflow of remittance money, prices of land in irrigated areas rose substantially, making it hard for migrants who were production-service workers before migration to buy pieces of land sufficient to provide for the livelihoods of their families. It is also likely that land-owners in irrigated areas were not keen to sell their land. Further, although the land in non-irrigated areas is not suited to agriculture, 'a high degree of interest [such as use of agricultural machinery and fertiliser] could sustain agricultural activity in this area' [Gilani (1986), p. 131]. Long durations of stay abroad could have created this high degree of interest among return migrants. [Gilani (1986), p. 126] reported certain cases of success in a non-irrigated Punjabi village, where migrant families maintained dairy farms alongside other agricultural activity. However, there is a strong possibility that return migrants who were able to stay abroad for longer periods and accumulated savings chose agricultural occupations because of the prestige attached to land.
} 
Table 5

Pre-migration Occupations of Return Migrants by Post-migration Occupations and Place of Residence

\begin{tabular}{|c|c|c|c|c|c|c|}
\hline \multirow{2}{*}{$\begin{array}{l}\text { Pre-migration } \\
\text { Occupation/ } \\
\text { Place of Residence }\end{array}$} & \multirow[b]{2}{*}{$\begin{array}{c}\text { Professional/ } \\
\text { Clerical }\end{array}$} & \multicolumn{4}{|c|}{ Post-migration Occupation } & \multirow[b]{2}{*}{$(\mathrm{N})$} \\
\hline & & Agriculture & Business & $\begin{array}{c}\text { Production/ } \\
\text { Service }\end{array}$ & Total & \\
\hline \multicolumn{7}{|l|}{ Rural Areas } \\
\hline Professional/Clerical & 34.2 & 26.3 & 26.3 & 13.2 & 100 & (38) \\
\hline Agriculture & 1.1 & 77.7 & 11.7 & 9.6 & 100 & (188) \\
\hline Business & 0.0 & 5.3 & 73.7 & 21.1 & 100 & $(57)$ \\
\hline Production/Service & 1.9 & 26.6 & 26.6 & 44.9 & 100 & $(376)$ \\
\hline \multicolumn{7}{|l|}{ Urban Areas } \\
\hline Professional/Clerical & 50.0 & 0.0 & 33.3 & 16.7 & 100 & (30) \\
\hline Agriculture & 2.5 & 22.5 & 40.0 & 35.0 & 100 & (40) \\
\hline Business & 2.0 & 2.0 & 76.0 & 20.0 & 100 & $(50)$ \\
\hline Production/Service & 2.7 & 0.9 & 36.2 & 60.2 & 100 & $(221)$ \\
\hline \multicolumn{7}{|l|}{ Total } \\
\hline Professional/Clerical & 41.2 & 14.7 & 29.4 & 14.7 & 100 & (68) \\
\hline Agriculture & 1.3 & 68.0 & 16.7 & 14.0 & 100 & (228) \\
\hline Business & 0.9 & 3.7 & 74.8 & 20.6 & 100 & (107) \\
\hline Production/Service & 2.2 & 17.1 & 30.2 & 50.6 & 100 & (597) \\
\hline
\end{tabular}


professional-clerical workers and 51 percent of production-service workers retained their pre-migration occupations after returning from the Middle East.

All panels of Table 5 are contingency tables classifying pre-migration occupation by post-migration occupation. Excluding the four 'no change' diagonal cells, 12 potential movements between pre-migration and post-migration occupations can be identified for each panel. These movements are shown in Appendix Table 7, where the category 'no change in occupation' indicates the share of diagonal cellsimmobility, constituting 56 percent. In other words, a substantial proportion of returning workers, 44 percent, changed their occupations after return. Migrants domiciled in irrigated areas were less inclined to change their occupations after returning than migrants from the other three geographical locations. The highest level of occupational change was observed in non-irrigated areas (Appendix Table 7).

As noted above, professional-clerical and production-service workers were relatively more inclined to change their occupations, and the most popular transition for them was to the business category. About 30 percent of migrants who had professional-clerical or production-service occupations before migration were occupied in business activities after migration (Table 5). Agriculture was the second most popular new occupation for professional-clerical and production-service workers. Controlling for rural-urban location makes even more clear the direction of occupational change. In rural areas, the business and agriculture categories showed similar attractions for production-service and professional-clerical workers. Twentysix percent of each of the latter two groups moved into each of the business and agriculture categories upon their return from abroad. Urban migrants were more inclined than rural migrants to have moved into business (Table 5).

The strong preference of return migrants for establishing independent work does not, however, necessarily mean that they were running large-scale businesses or farms. Rather, in view of the limited resources created by foreign remittances, it is not difficult to imagine that most of them were able to set up businesses and farms only on a very small scale. Distributions of return migrants engaged in business after migration by type of business, controlled for geographical location and duration of stay abroad, are shown in Table 6. Seventy-three percent of rural migrants in the business category were in retail trade (including restaurants and hotels), and 16 percent were in transport. The proportion of business workers who opened a workshop $^{9}$ was about 8 percent, and another 4 percent were involved in manufacturing of goods. The pattern in urban areas was similar, except that transport was somewhat less important and operating a workshop was more important than in rural areas.

Table 6 shows that there are differences in types of business within rural and urban areas. Workshops and manufacturing appear to be more important in the

${ }^{9}$ In the ILO survey a workshop refers to a shop which provides services to repair machinery, such as tractor, motor cycle and car, and electrical appliances. 
MUCs than in the OUCs. The concentration on transport was greater in nonirrigated areas than in other geographical locations. Although duration of stay abroad was positively related to entering business, it has little influence on types of business engaged in (Table 6). ${ }^{10}$

Table 6

Percentage Distributions of Return Migrants who were Business Workers after Return by Type of Business, Controlling for Geographical Location and Duration of Stay Abroad

\begin{tabular}{|c|c|c|c|c|c|}
\hline \multirow[b]{2}{*}{ Location/Duration } & \multicolumn{3}{|c|}{ Types of Business } & \multirow[b]{2}{*}{ Workshop } & \multirow[b]{2}{*}{ Total } \\
\hline & $\begin{array}{l}\text { Manufac- } \\
\text { turing }\end{array}$ & $\begin{array}{l}\text { Retail } \\
\text { Trade }\end{array}$ & Transportation & & \\
\hline \multicolumn{6}{|l|}{ Geographical } \\
\hline \multicolumn{6}{|l|}{ Location } \\
\hline Urban Areas & 6 & 72 & 10 & 12 & 100 \\
\hline MUCs & 7 & 70 & 7 & 16 & 100 \\
\hline OUCs & 2 & 77 & 15 & 6 & 100 \\
\hline Rural Areas & 4 & 73 & 16 & 7 & 100 \\
\hline Irrigated & 1 & 79 & 11 & 9 & 100 \\
\hline Non-irrigated & 6 & 68 & 19 & 7 & 100 \\
\hline \multicolumn{6}{|l|}{$\begin{array}{l}\text { Duration of Stay } \\
\text { Abroad }\end{array}$} \\
\hline Short-stayers & 3 & 75 & 11 & 11 & 100 \\
\hline Medium-stayers & 5 & 71 & 13 & 11 & 100 \\
\hline Long-stayers & 7 & 72 & 14 & 7 & 100 \\
\hline Total & 5 & 72 & 13 & 10 & 100 \\
\hline
\end{tabular}

Source: Computed from the 1986 ILO survey data.

The foregoing analysis has established that in agreement with a priori expectation a considerable proportion of return migrants changed their pre-migration occupations upon returning to Pakistan and engaged primarily in business activities and, to a lesser extent, in the agriculture sector. One issue which needs to be addressed is the possibility that employment trends exhibited by the returnee sample are broadly consonant with employment changes that have occurred in the general population of Pakistan, so that migration may have had little influence on the change. To explore this issue, it is common in return migration studies to compare the postmigration occupations of return migrants with the occupations of the general

${ }^{10}$ Another way to examine the scale of businesses established by return migrants is to relate the type of business with the amount of investment. The ILO data show that three-quarters of returnees involved in business invested an amount of 50,000 rupees or less. In the case of those running workshops and employed in trade, this increased to 90 and 79 percent respectively. 
population [Alvarez (1967), p. 93; King et al. (1984), p. 118; Gmelch (1987), p. 134]. Distributions of the employed population of Pakistan by major occupational groups shows no marked change in the occupational composition of the general population between 1971 and 1987. Throughout this period, agriculture remained the dominant sector for employment. However, its share declined from 57 percent in 1971-72 to 48 percent in 1986-87, and the share of production-service sector rose by 5 percent (Table 7).

Table 7

Percentage Distributions of the Employed Population of Pakistan by Major Occupational Groups by Rural-urban Residence, 1971-87

\begin{tabular}{lccccccc}
\hline Occupations & $1971-72$ & $1974-75$ & $1978-79$ & $1982-83$ & $1984-85$ & $1985-86$ & $1986-87$ \\
\hline Professional & 4.9 & 6.4 & 6.7 & 6.9 & 7.8 & 7.8 & 8.5 \\
Agriculture & 57.2 & 54.7 & 52.6 & 52.8 & 50.1 & 53.5 & 48.8 \\
Business & 12.1 & 10.0 & 10.1 & 10.2 & 10.2 & 10.2 & 11.3 \\
Production/Service & 25.8 & 28.9 & 30.6 & 30.1 & 31.9 & 28.5 & 31.3 \\
Total & 100.0 & 100.0 & 100.0 & 100.0 & 100.0 & 100.0 & 100.0 \\
\hline
\end{tabular}

Source: Government of Pakistan (1990), Table 4.3.

Thus it can be concluded that the employment trends exhibited by the returnee sample were not consonant with employment changes occurring in the general population. In the context of the prevailing socio-economic structure of Pakistan, where job opportunities are very limited and the chances of occupational mobility, particularly in rural areas, are poor, the types of occupational changes experienced by return migrants are not usual for them. Overseas migration seems to have raised the occupational status of many returning workers and their families. While there is no way of knowing what a person would have achieved had he not migrated, there was a definite positive relationship between duration of stay abroad and degree of occupational independence on return (hypothesis 2).

However, the conclusion that overseas migration raised the occupational status of many returning workers who moved into self-employment might be questioned on the ground that these migrants may have faced very insecure futures. Their success will have depended a great deal on the stability of businesses (and farms) they established after return, and the possibility of business failure cannot be ruled out. In the event of failure, there may have been a drift back toward premigration occupations. However, according to Kazi (1989, p. 180), “despite the fact that a large proportion of entrepreneurs [in the ILO/ARTEP sample] were new entrants in the field, the rate of business failure was not high. The rate was 15 percent for urban and 11 percent for rural areas". The primary factors in the failure were shortage of funds and personal problems. 


\section{RETURN MIGRATION AND OCCUPATIONAL CHANGE: THE EXPERIENCE OF OTHER ASIAN COUNTRIES}

The tendency for Pakistani migrants to change occupation upon returning home and to shift to self-employment by establishing businesses and farms is in tune with experience elsewhere. In Table 8, proportions of return migrants self-employed before migration and after return for selected countries are compared with the situation of Pakistani return migrants. Migrants who nominated business or agriculture as their economic activity were considered self-employed. In Kerala (India), about 62 percent of return migrants were reported to be self-employed after their return from Middle East employment, and this level of self-employment was three times the pre-migration level. In Bangladesh, the proportion of return migrants self-employed increased from 41 percent before migration to 58 percent after migration, and for Korea from 11 to 25 percent.

Table 8

Proportion of Migrants Self-employed before Migration and after Return from Overseas Employment: Selected Asian and Non-Asian Labour-exporting Countries

\begin{tabular}{lcccl}
\hline & & \multicolumn{2}{c}{ Percentage Self-employed } & \multicolumn{1}{c}{ Source } \\
Country of Origin & Year & Before Migration & After Migration & \\
\cline { 1 - 1 } Asian Countries & & & 59 & ILO/ARTEP Survey (1987) \\
Pakistan & 1986 & 34 & 58 & Mahmood (1991) \\
Bangladesh & 1986 & 41 & 63 & Nair (1991) \\
Kerala (India) & 1986 & 21 & 16 & Athukorala (1990) \\
Sri Lanka & 1986 & 10 & 25 & Seok (1991) \\
Korea & 1986 & 11 & & \\
Non-Asian Countries & & & 49 & Paine (1974) \\
$\quad$ Turkey & 1978 & 36 & 33 & King et al. (1984) \\
Italy & 1982 & 25 & & \\
\hline
\end{tabular}

The proportion self-employed in Sri Lanka increased from 10 percent before migration to 16 percent upon returning from abroad (Table 8). The main reason for this low percentage is that more than half of Sri Lankan migrants were female workers who were housewives before migration, and most of them became housewives again on return [Athukorala (1990), p. 335]. Two non-Asian countries, Turkey and Italy, which exported their labour to Western European countries in the 1960s and 1970s, are also included in Table 8. About half of return migrants in Turkey and one-third in Italy were self-employed after return, these levels being considerably higher than pre-migration levels. 


\section{DETERMINANTS OF OCCUPATIONAL CHANGE}

The bivariate analysis carried out in Sections 5 and 6 shows that migrants' post-return occupational composition was substantially different from their premigration and during-migration compositions, and migrants who changed their occupation upon return engaged primarily in business activities and to a lesser extent in the agriculture sector. Although geographical location and migrants' duration of stay abroad appear to be important determinants of this change, the foregoing analyses do not facilitate an examination of the effect of some other important background characteristics such as age, education, and remittances on the postmigration occupational shifts. To accomplish this, multivariate techniques were employed to examine the factors affecting migrants' decision to change their premigration occupations after return.

For the first series of regressions, the dependent variable is a binary measure equalling unity if the post-migration occupation of a return migrant was different from his pre-migration one, and zero if it was the same. A methodological caveat is appropriate here. Specifying the dependent variable as whether or not occupational change occurred prohibits modelling the direction of occupational mobility. Alternative specifications would include upward or downward mobility as a dependent variable. However, as noted in Section 4, in view of the strong preference of return migrants for becoming self-employed, much doubt can be cast upon the validity of such directional models. As an alternative, models explaining the dominance of business and agriculture were estimated separately. To explain the dominance of business occupations, logistic regression was also employed using a binary dependent variable equalling unity if the migrant switched to the business category after his return from the Middle East, and zero if he did not. To explain the dominance of agricultural occupations in rural areas, logistic regression was employed using a binary dependent variable equalling unity if the migrant moved to an agricultural occupation after his return from the Middle East, and zero if he did not. The independent variables were return migrant's age at the time of return, level of educational attainment, duration of stay in the Middle East, volume of total remittances, and geographical location. Operational definitions of these variables are presented in Table 9. There was no correlation between the independent variables.

Consideration is first given to models focusing on whether occupational change occurred (Table 10). For all migrants, all independent variables turned out to be statistically significant. The signs of coefficients for categories of these variables are as expected. For example, age of migrant at the time of return had a negative influence on the likelihood of occupational change. In Pakistan the extended family system plays a vital role in delegating authority, and according to Altaf (1983, p.111), age is indicative of both levels of authority and responsibility. Older return migrants were likely to have been heads of households and responsible for the 
Table 9

Operational Definitions of Explanatory Variables Used in the Logistic Regression Analysis of Occupational Change after Return

\begin{tabular}{ll}
\hline Variable Name & \multicolumn{1}{c}{ Variable Specification } \\
\hline Age at the Time of Return & $\begin{array}{l}\text { Age at the time of return in completed years is a } \\
\text { categorical variable, and takes the value One if the } \\
\text { respondent was aged less than } 30 \text { years, Two if aged } \\
\text { between } 30 \text { and } 39 \text { years, and Three if aged } 40 \text { years or } \\
\text { more. } \\
\text { Level of educational attainment takes the value One if } \\
\text { the respondent was illiterate, Two if educated to pre- } \\
\text { matriculation level, and Three if educated to } \\
\text { matriculation level or above. }\end{array}$ \\
Feographical Location & $\begin{array}{l}\text { MuCs, and the OUCs, were entered in the model as } \\
\text { dummy variables. }\end{array}$ \\
Length of Stay Abroad & $\begin{array}{l}\text { Length of stay abroad (in completed years) takes the } \\
\text { value One if the respondent was a short-stayer, Two if a } \\
\text { medium-stayer, and Three if a long-stayer. } \\
\text { Total amount of remittances at the time of return takes } \\
\text { the value One if they were less than 100,000 rupees, } \\
\text { and Two if 100,000 rupees or more. }\end{array}$ \\
\hline
\end{tabular}

livelihood of household members. It seems that they preferred to stay in their premigration occupations to avoid the risk associated with new jobs. It is also possible that migration by younger persons was associated with plans to marry and set up independent households, and that occupational mobility was linked to this. Thus it would not be unfair to deduce that the younger the return migrant, the greater the chance of occupational mobility.

Table 10 shows that higher levels of educational attainment raised significantly the probability of switching jobs after return (hypothesis 3 ). It is worthy of note that 58 percent of return migrants in the ILO sample with matriculation or better levels of education changed their occupations upon return, while the corresponding figures for illiterate and less educated workers were 33 and 46 percent respectively (Appendix Table 8). For migrants with matriculation or higher levels of education, 60 percent of those who changed their occupations moved to the business category, primarily from the production-service sector. Why was education positively related with occupational change? It was noted in Section 2 that general education is still believed in Pakistan to be a path to government service, but return migrants 
Table 10

Logistic Regression of whether or not Migrants' Occupations Changed after Return from the Middle East, by Rural-urban Origin

\begin{tabular}{|c|c|c|c|}
\hline \multirow[b]{2}{*}{ Variables } & \multicolumn{3}{|c|}{ Occupational Change } \\
\hline & All Migrants & Rural Origin & Urban Origin \\
\hline \multicolumn{4}{|c|}{ Age at the Time of Return } \\
\hline$<30$ Years & - & - & - \\
\hline 30-39 Years & $-0.30^{* *}$ & 0.25 & -0.49 \\
\hline$\geq 40$ Years & 0.01 & 0.05 & -0.16 \\
\hline \multicolumn{4}{|l|}{$\begin{array}{l}\text { Level of Educational } \\
\text { Attainment }\end{array}$} \\
\hline Illiterate & - & - & - \\
\hline Pre-matriculation & $0.56 *$ & $0.59 *$ & $0.61^{*}$ \\
\hline Matriculation + & $0.98 *$ & $0.81 *$ & $1.11^{*}$ \\
\hline \multicolumn{4}{|c|}{ Duration of Stay Abroad } \\
\hline Short-stayers & - & - & - \\
\hline Medium-stayers & 0.09 & 0.03 & 0.49 \\
\hline Long-stayers & $0.55^{*}$ & 0.11 & $1.64^{*}$ \\
\hline \multicolumn{4}{|l|}{$\begin{array}{l}\text { Volume of Total } \\
\text { Remittances }\end{array}$} \\
\hline$<100,000$ Rupees & - & - & - \\
\hline$\geq 100,000$ Rupees & $0.46^{*}$ & $0.47 *$ & 0.32 \\
\hline \multicolumn{4}{|c|}{ Geographical Location } \\
\hline Irrigated & - & - & - \\
\hline Non-irrigated & $0.41^{*}$ & - & - \\
\hline MUCs & -0.01 & - & \\
\hline OUCs & -0.01 & - & \\
\hline Intercept & $-1.07 *$ & $-0.76^{*}$ & $-1.41^{*}$ \\
\hline $\mathrm{LR} X^{2}$ & 1367 & 872 & 413 \\
\hline$(\mathrm{N})$ & 1000 & 659 & 341 \\
\hline
\end{tabular}

Source: Computed from the 1986 ILO survey data.

* Shows significance at 95 percent level of confidence or better.

** Shows significance at 90 percent level of confidence or better.

could be at a disadvantage here because often their overseas work experience is not directly related to the requirements of jobs in the public sector. Independent work, which can be seen as a guarantee of more security, comfort and status, appears to be the best alternative for educated returnees. It is not uncommon for educated rural 
workers to migrate to urban centres for jobs, but, according to Ballard (1987, p. 36), "only rarely do they get regular jobs, which are extremely hard to find". Migration, mainly through remittances, seems to have provided educated returnees with opportunities to establish independent work in their areas of origin.

Two migration-related variables, duration of stay abroad and size of remittances, also raised the probability of changing jobs (Table 10). This shows the importance of Middle East migration in providing migrant workers with opportunities to establish independent work. It has been noted earlier that the majority of the urban and rural population alike was involved before migration in the poorly-paid, low-status production-service sector; there should be great motivation for them to change their occupations. However, limited economic resources available to individuals and households seem to hinder progress in that direction. Migration has provided these resources, and many migrants who stayed abroad for relatively long periods and accumulated sufficient savings left their pre-migration occupations to seek independent work.

Table 10 (all migrants) shows that return migrants located in non-irrigated areas were more likely to change jobs than returnees in other locations. Determinants of occupational change revealed by rural and urban models are also shown in Table 10. Age of migrant at the time of return, which was negatively significant for all migrants, did not turn out to be statistically significant in either the rural or the urban model. Duration of stay abroad raised the probability only of urban migrants switching jobs after their return, while for rural migrants remittance money seems to have been important in providing opportunities for occupational change. Education showed a significant and positive influence on the probability of changing jobs after return for both rural and urban migrants.

Table 11 presents logistic regression coefficients associated with the probabilities of moving to business and agriculture occupations after returning from the Middle East among those who had changed their occupation after return. All variables included in Table 10 (all migrants) were entered into these models. The model specified for those who switched to business shows a pattern which closely mirrors that of the models with occupational change as the dependent variable. Four variables-education, duration of stay abroad, remittances, and geographical location-which were statistically significant in the occupational change model (all migrants) also turned out to be significant in the business employment equation. In both cases, the signs of significant categories of variables were also the same, except that in the occupational change model, the coefficient for non-irrigated areas was significant, while in the business employment equation, the coefficient for the MUCs turned out to be significant. The results presented in Table 11, when compared with those in Table 10, suggest that occupational change experienced by migrants upon 
Table 11

Logistic Regression of Movement into Business and Agriculture after Return from the Middle East by Return Migrants who Changed their Occupations

\begin{tabular}{lcc}
\hline Variables & Business & Agriculture \\
\hline Age at the Time of Return & & - \\
$\quad<30$ Years & - & -0.19 \\
30-39 Years & -0.02 & 0.34 \\
$\geq 40$ Years & -0.37 & \\
Level of Educational Attainment & & - \\
$\quad$ Illiterate & - & $-0.51^{* *}$ \\
Pre-matriculation & $0.59^{*}$ & $-1.09^{*}$ \\
Matriculation & 0.34 & \\
Duration of Stay Abroad & & - \\
$\quad$ Short-stayers & - & $-0.63^{*}$ \\
Medium-stayers & $0.65^{*}$ & $-0.65^{*}$ \\
Long-stayers & $0.79^{*}$ & \\
Volume of Total Remittances & & - \\
$\quad<100,000$ & - & 0.47 \\
$>100,000$ & -0.02 & \\
Geographical Location & & - \\
Irrigated & - & - \\
Non-irrigated & 0.14 & - \\
MUCs & $1.08^{*}$ & - \\
OUCs & 0.59 & -0.28 \\
Intercept & $0.77^{*}$ & 364 \\
LR $X^{2}$ & 551 & 434 \\
$\mathrm{~N}$ & 434 & \\
\hline
\end{tabular}

Source: 1986 ILO survey.

Note: * Shows significance at 95 percent level or better.

** Shows significance at 90 percent level or better.

their return was mainly towards the business sector, and education, duration of stay abroad, and geographical location were the most important determinants of returnees' decision to move into businesses during the post-migration phase.

Re-specifying the dependent variable to explain return migrants' decisions to engage in agriculture demonstrates a pattern opposite to the business employment 
one (Table 11). Education and duration of stay abroad, which showed positive influences on switching to business, had significant negative effects on moving into agriculture after migration. Stauth (1987, p. 740) suggested from the Egyptian case that returnees tended to avoid agricultural and peasant work. The case of Pakistan seems to be similar to the Egyptian case, since it is apparent from the present analysis that education and duration of stay abroad had a negative influence on the probabilities of moving to agriculture after return from the Middle East, probably because of a strong preference of workers to be involved in business activities.

\section{CONCLUSION}

In this study three issues related to post-migration occupational change of return migrants were explored: the comparison with pre-migration and duringmigration occupational compositions, the directions of occupational change, and the factors affecting these changes after return. About half of the total employed in ILO sample, 44 percent, changed their pre-migration occupations upon return, mainly from production-service occupation to small businesses. The highest level of occupational change was observed in non-irrigated areas. The occupational change was strongly related to migrants' durations of stay in the Middle East, their ages at the time of return, and their level of educational attainment. The model specified for those who switched to business shows a pattern which closely mirrors that of the models with occupational change, suggesting that occupational mobility experienced by returnees was mainly towards the business sector. However, the analysis shows that the effects of education and duration of stay abroad were negative for making the transition to agriculture, probably because of a strong preference of workers to be involved in business activities. This preference seems to be in a direction approved by the Government of Pakistan, which has been promoting self-employment among return migrants. It is also possible that movement of return migrants on a large scale into business might have given other young educated (particularly unemployed) persons in the country the incentive to become self-employed rather than look for jobs in the saturated public sector.

It is beyond the scope of this paper to examine the consequences of occupational change experienced by migrant workers upon their return from the Middle East. Nevertheless, overseas migration appears to be beneficial to migrant workers and their families. It is generally believed that during the period of migration these families, because of inflow of remittances, enjoy higher standards of living than they would otherwise. The preference of returnees to work independently might have enabled them to earn sufficient money to maintain these standards beyond the period of migration. In view of the concentration of workers in low-status jobs before migration, the occupational shifts are likely to have raised their social status as well. 


\section{POLICY IMPLICATIONS}

Occupational mobility experienced by returnees was mainly towards the business sector. This mobility can be more beneficial if it leads to stable subsequent employment. To achieve such stability, keeping in view the possibility of business failure, there is a need to provide short-term assistance to returnees mainly in the form of training and credit. It would be advisable for the Overseas Pakistanis Foundation, an organisation set up by the Government of Pakistan in 1979 to look after the welfare of migrants, to provide both instruction and extension services to returnees to aid them in managing small businesses, particularly in high-migration areas. A project-oriented training course and a loan scheme can be the two basic elements of these services. The aim of the training course should be to help participants to identify and develop small-scale business projects and to acquaint themselves with basic business management practices required to run a small business. The loan scheme can be designed to provide the participants with supplementary finance through banks for the implementation of projects developed during the training course.

The present study has shown that the mobility of workers towards business sector was strongly related to their duration of stay in the Middle East. It appears that a longer duration of stay enabled migrants to accumulate savings. A substantial proportion of these savings was probably used by migrants and their families to establish small businesses after return. The length of stay abroad thus seems to be a crucial factor to aid workers and their families to enhance their socio-economic status. Several individual-level factors, such as age, education and occupation, and policies of the country of employment usually determine workers' length of stay. But, it may be closely related to the process of recruitment. In Pakistan the assistance to migrate provided through government agencies and servicing institutions is minimal, and prospective migrants depend greatly on private recruiting agencies; fraud and irregularities are common. In the absence of any systematic surveillance of the recruiting process, the incidence of illegal migration has increased over time [Stahl and Azam (1990)], and probably many return migrants who failed to stay abroad even for a period of two years were illegal. The best government initiative to aid the workers returning from overseas employment would be one that aimed at improving the process of recruitment.

Finally, the temporary nature of the contract labour migration process needs to be emphasised. Migrants need to be made to realise that their residence away from home is a temporary phase, and that resettlement in Pakistan will eventually take place. In the long run, it could also be useful to encourage migrants to plan for the post-return phase even before departing for overseas employment. However, they should also be warned that their long-term gain from migration is likely to be limited

unless they are able to secure, and are prepared to stay abroad for, more than the period of one contract, which is usually two years. 
Appendix Table 1

Selected Districts, Tehsils (Sub-districts), and Cities for the

Sample of the 1986 ILO Survey

\begin{tabular}{|c|c|c|c|}
\hline Province & $\begin{array}{l}\text { Selected } \\
\text { Districts }\end{array}$ & $\begin{array}{l}\text { Selected Tehsils } \\
\text { for Rural Sample }\end{array}$ & $\begin{array}{l}\text { Selected Cities/Towns } \\
\text { Urban Sample }\end{array}$ \\
\hline \multirow{17}{*}{ Punjab } & Lahore & Lahore & Lahore \\
\hline & Gujrat & Kharian, Gujrat & - \\
\hline & Jhelum & Jhelum, & - \\
\hline & & Pind Daden Khan & - \\
\hline & Chakwal & Chakwal & Chakwal \\
\hline & Sialkot & Sialkot, Daska & Sialkot \\
\hline & Gujranwala & Wazirabad & - \\
\hline & & Hafizabad & - \\
\hline & & Gujranwala & Gujranwala \\
\hline & & Eminabad & - \\
\hline & Rawalpindi & - & Rawalpindi \\
\hline & Bahawalpur & Bahawalpur & Bahawalpur \\
\hline & Muzaffargarh & Alipur & - \\
\hline & & Muzaffargarh & - \\
\hline & Leiah & Leiah & - \\
\hline & Faisalabad & Summundari & Faisalabad \\
\hline & Toba Tek Sing & Toba Tek Sing & - \\
\hline \multirow[t]{7}{*}{ Sindh } & Karachi & - & Karachi \\
\hline & Sukkur & Ghotki, Mirpur & - \\
\hline & & Mathelo, Pannu Aqil & - \\
\hline & Hyderabad & Tando Allah Yar & Hyderabad \\
\hline & & Hala & - \\
\hline & Sanghar & Sanghar, Shahdadpur & - \\
\hline & Larkana & Larkana, Wara & - \\
\hline \multirow[t]{7}{*}{ NWFP } & Peshawar & Nowshera & Peshawar, Pubbi \\
\hline & & & Jehangira, \\
\hline & & & Nowshera \\
\hline & Kohat & Kohat & Kohat \\
\hline & Mardan & Mardan & - \\
\hline & Abbottabad & Abbottabad & - \\
\hline & Swat & Bobazi, Swat & - \\
\hline \multirow[t]{3}{*}{ AJK } & Rawalakot & Rawalakot & - \\
\hline & Kotli & Kotli & - \\
\hline & Mirpur & - & Mirpur \\
\hline
\end{tabular}

Source: ILO-ARTEP (1987b: Annexure viii). 
Appendix Table 2

Regional and Rural-urban Distribution of Return Migrants Covered in the 1986 ILO-ARTEP Survey before and after Data Cleaning

\begin{tabular}{|c|c|c|c|c|c|c|}
\hline \multirow{2}{*}{$\begin{array}{c}\text { Province/ } \\
\text { Region }\end{array}$} & \multicolumn{2}{|c|}{ Rural } & \multicolumn{2}{|c|}{ Urban } & \multicolumn{2}{|c|}{ Total } \\
\hline & $\mathrm{N}$ & $\%$ & $\mathrm{~N}$ & $\%$ & $\mathrm{~N}$ & $\%$ \\
\hline \multicolumn{7}{|c|}{ Before Data Cleaning } \\
\hline Punjab & 462 & 56.1 & 227 & 45.0 & 689 & 51.9 \\
\hline Sindh & 101 & 12.3 & 133 & 26.4 & 234 & 17.6 \\
\hline NWFP & 181 & 22.0 & 117 & 23.0 & 298 & 22.5 \\
\hline AJK & 79 & 9.6 & 27 & 5.4 & 106 & 8.0 \\
\hline $\begin{array}{l}\text { Total Sample } \\
\text { (\%) }\end{array}$ & 823 & $\begin{array}{l}100.0 \\
(62.0)\end{array}$ & 504 & $\begin{array}{l}100.0 \\
(38.0)\end{array}$ & 1327 & $\begin{array}{c}100.0 \\
(100.0)\end{array}$ \\
\hline \multicolumn{7}{|c|}{ After Data Cleaning } \\
\hline Punjab & 448 & 55.6 & 212 & 47.6 & 660 & 52.8 \\
\hline Sindh & 121 & 15.0 & 98 & 22.0 & 219 & 17.5 \\
\hline NWFP & 159 & 19.7 & 108 & 24.3 & 267 & 21.3 \\
\hline AJK & 78 & 9.7 & 27 & 6.1 & 105 & 8.4 \\
\hline $\begin{array}{l}\text { Total Sample } \\
\text { (\%) }\end{array}$ & 806 & $\begin{array}{l}100.0 \\
(64.4)\end{array}$ & 445 & $\begin{array}{l}100.0 \\
(35.6)\end{array}$ & 1251 & $\begin{array}{c}100.0 \\
(100.0)\end{array}$ \\
\hline
\end{tabular}

Source: Computed from the 1986 ILO survey data.

Note: Row-wise percentages of the total ILO sample are given in parentheses.

Appendix Table 3

Distribution of Return Migrants by Province and by Type of Rural and Urban Area

\begin{tabular}{lcccrc}
\hline Rural/Urban & Punjab & Sindh & NWFP & AJK & Total \\
\hline Urban Areas & 212 & 98 & 108 & 27 & 445 \\
MUCs & 160 & 98 & 44 & 0 & 302 \\
OUCs & 52 & 0 & 64 & 27 & 143 \\
Rural Areas & 448 & 121 & 159 & 78 & 806 \\
$\quad$ Irrigated & 203 & 121 & 40 & 0 & 364 \\
$\quad$ Non-irrigated & 245 & 0 & 119 & 78 & 442 \\
Total Sample & 660 & 219 & 267 & 105 & 1251 \\
(\%) & $(52.8)$ & $(17.5)$ & $(21.3)$ & $(8.4)$ & $(100.0)$ \\
\hline
\end{tabular}

Source: Computed from the 1986 ILO survey data.

\section{Appendix Table 4}

Percentage Distribution of Return Migrants by Duration of Stay Abroad, Controlling by Geographical Location

\begin{tabular}{|c|c|c|c|c|c|c|c|}
\hline \multirow[b]{2}{*}{$\begin{array}{l}\text { Duration of } \\
\text { Stay Abroad }\end{array}$} & \multicolumn{3}{|c|}{ Rural Areas } & \multicolumn{3}{|c|}{ Urban Areas } & \multirow[b]{2}{*}{ Total } \\
\hline & Irrigated & $\begin{array}{l}\text { Non- } \\
\text { irrigated }\end{array}$ & $\begin{array}{l}\text { All } \\
\text { Rural }\end{array}$ & MUCs & OUCs & $\begin{array}{l}\text { All } \\
\text { Urban }\end{array}$ & \\
\hline Short-stayers & 45.1 & 34.3 & 39.3 & 30.6 & 25.9 & 29.0 & 35.8 \\
\hline Medium-stayers & 37.9 & 48.4 & 43.6 & 51.1 & 47.3 & 49.9 & 45.7 \\
\hline Long-stayers & 17.0 & 17.3 & 17.1 & 18.3 & 26.8 & 21.1 & 18.5 \\
\hline All & 100.0 & 100.0 & 100.0 & 100.0 & 100.0 & 100.0 & 100.0 \\
\hline $\begin{array}{l}\text { Average Length } \\
\text { of Stay (Years) }\end{array}$ & 3.4 & 3.6 & 3.5 & 3.7 & 4.3 & 3.9 & 3.6 \\
\hline
\end{tabular}

Source: Computed from the 1986 ILO survey. 
Appendix Table 5

Percentage Distribution of Return Migrants by Occupations Held before Migration, while Abroad, and after Return

\begin{tabular}{|c|c|c|c|}
\hline Occupations & Before Migration & While Abroad & After Return \\
\hline Professional/ Technical Workers & 2.5 & 4.1 & 2.5 \\
\hline Doctors/Medical Assistants & 0.2 & 0.2 & 0.2 \\
\hline Engineers & 0.5 & 0.4 & 0.2 \\
\hline Lecturers/Teachers & 1.0 & 0.3 & 1.4 \\
\hline Technologists & 0.3 & 1.6 & 0.5 \\
\hline Supervisors & 0.1 & 1.3 & 0.1 \\
\hline Other Professionals & 0.4 & 0.3 & 0.1 \\
\hline Clerical Workers & 4.3 & 1.5 & 2.0 \\
\hline Clerks/Stenographers & 3.6 & 1.0 & 1.2 \\
\hline Storekeepers (Record Keepers) & 0.0 & 0.5 & 0.0 \\
\hline Draftsmen & 0.2 & 0.0 & 0.2 \\
\hline Other Clerical Workers & 0.5 & 0.0 & 0.6 \\
\hline Service Workers & 10.9 & 17.1 & 9.1 \\
\hline Cooks & 0.4 & 1.1 & 0.1 \\
\hline Drivers & 6.9 & 7.6 & 4.4 \\
\hline Tailors & 2.2 & 2.3 & 2.2 \\
\hline Domestic Help Servants & 0.5 & 4.7 & 0.6 \\
\hline Waiters & 0.2 & 0.5 & 0.2 \\
\hline Other Service Workers & 0.7 & 0.9 & 1.6 \\
\hline Skilled Workers & 27.7 & 34.9 & 17.7 \\
\hline Carpenters & 3.7 & 5.0 & 3.3 \\
\hline Electricians & 3.1 & 3.0 & 0.8 \\
\hline Masons & 8.4 & 8.6 & 8.0 \\
\hline Mechanics & 1.7 & 1.8 & 1.0 \\
\hline Operators & 1.6 & 3.1 & 0.3 \\
\hline Pipe-fitters & 1.9 & 2.2 & 0.4 \\
\hline Painters & 0.6 & 1.2 & 0.3 \\
\hline Steel-workers & 1.6 & 3.0 & 1.3 \\
\hline Plumbers & 0.4 & 1.0 & 0.2 \\
\hline Weavers & 1.0 & 0.5 & 0.9 \\
\hline Welders & 1.2 & 1.9 & 0.1 \\
\hline Other Skilled Workers & 2.5 & 3.6 & 1.1 \\
\hline Labourers/Unskilled Workers & 21.1 & 39.3 & 9.8 \\
\hline Agricultural Workers & 22.8 & 1.4 & 31.8 \\
\hline Business Workers & 10.7 & 1.7 & 27.1 \\
\hline$(\mathrm{N})$ & $(1000)$ & $(1000)$ & $(1000)$ \\
\hline
\end{tabular}

Source: Computed from the 1986 ILO Survey. 
Appendix Table 6

Return Migrants in Pre-migration Occupational Categories Distributed by Occupation while Abroad

\begin{tabular}{|c|c|c|c|c|c|c|c|c|c|c|}
\hline \multirow{2}{*}{$\begin{array}{l}\text { Pre-migration } \\
\text { Occupations }\end{array}$} & \multicolumn{9}{|c|}{ Occupations while Abroad (\%) } & \multirow[b]{2}{*}{$(\mathrm{N})$} \\
\hline & Professional & Clerical & Service & Agriculture & Business & Skilled & Unskilled & Others & Total & \\
\hline Professional & 65.8 & 2.6 & 2.7 & 0.0 & 0.0 & 21.1 & 5.3 & 2.7 & 100 & $(38)$ \\
\hline Clerical & 6.6 & 19.7 & 19.7 & 1.6 & 8.2 & 14.8 & 26.2 & 3.3 & 100 & $(61)$ \\
\hline Service & 2.0 & 1.4 & 60.5 & 0.0 & 0.7 & 15.0 & 19.0 & 1.4 & 100 & $(147)$ \\
\hline Agriculture & 1.7 & 0.8 & 11.0 & 2.5 & 0.4 & 14.8 & 68.2 & 0.4 & 100 & $(236)$ \\
\hline Business & 1.6 & 2.4 & 16.0 & 0.8 & 3.2 & 40.8 & 33.6 & 1.6 & 100 & (125) \\
\hline Skilled & 6.4 & 0.0 & 7.5 & 0.9 & 1.2 & 69.9 & 13.6 & 0.6 & 100 & (345) \\
\hline Unskilled & 2.0 & 0.0 & 17.6 & 3.4 & 1.5 & 15.1 & 60.0 & 0.5 & 100 & (205) \\
\hline Total Sample & 5.8 & 1.8 & 18.9 & 1.4 & 1.8 & 34.4 & 36.0 & 0.9 & 100 & (1251) \\
\hline
\end{tabular}

Source: Computed from the 1986 ILO survey data. 
Appendix Table 7

Percentage Distribution of Return Migrants, who Changed Occupations, by Direction of Occupational Movement by Rural-urban Areas and Duration of Stay in the Middle East

\begin{tabular}{|c|c|c|c|c|c|c|c|c|c|c|c|}
\hline \multirow[b]{2}{*}{$\begin{array}{c}\text { Pre-migration } \\
\text { Occupation }\end{array}$} & \multirow[b]{2}{*}{$\begin{array}{l}\text { Post-migration } \\
\text { Occupation } \\
\end{array}$} & \multicolumn{3}{|c|}{ Rural Areas } & \multicolumn{3}{|c|}{ Urban Areas } & \multicolumn{3}{|c|}{ Duration of Stay Abroad } & \multirow[b]{2}{*}{ Total } \\
\hline & & Irrigated & $\begin{array}{c}\text { Non- } \\
\text { irrigated }\end{array}$ & All Rural & MUCs & OUCs & All Urban & $\begin{array}{l}\text { Short- } \\
\text { Stayers }\end{array}$ & $\begin{array}{l}\text { Medium- } \\
\text { Stayers }\end{array}$ & $\begin{array}{l}\text { Long- } \\
\text { Stayers }\end{array}$ & \\
\hline \multicolumn{2}{|c|}{ No Change in Occupation } & 60.8 & 52.1 & 56.1 & 57.6 & 56.3 & 57.2 & 64.0 & 56.5 & 42.2 & 56.5 \\
\hline \multicolumn{2}{|c|}{ Change in Occupation } & 39.2 & 47.9 & 43.9 & 42.4 & 43.7 & 42.8 & 36.0 & 43.5 & 57.8 & 43.5 \\
\hline Professional & Business & 1.6 & 1.4 & 1.5 & 4.0 & 0.9 & 2.9 & 1.1 & 2.2 & 3.2 & 2.0 \\
\hline Professional & Agriculture & 1.3 & 1.7 & 1.5 & 0.0 & 0.0 & 0.0 & 0.6 & 0.9 & 2.2 & 1.0 \\
\hline Professional & Production & 1.0 & 0.6 & 0.8 & 1.7 & 0.9 & 1.5 & 0.8 & 0.8 & 1.6 & 1.0 \\
\hline Agriculture & Professional & 0.3 & 0.3 & 0.3 & 0.0 & 0.9 & 0.3 & 0.3 & 0.2 & 0.5 & 0.3 \\
\hline Agriculture & Business & 2.9 & 3.7 & 3.3 & 3.5 & 7.0 & 4.7 & 2.5 & 4.2 & 5.4 & 3.8 \\
\hline Agriculture & Production & 3.3 & 2.3 & 2.7 & 3.9 & 4.5 & 4.0 & 3.9 & 3.5 & 1.1 & 3.2 \\
\hline Business & Professional & 0.0 & 0.0 & 0.0 & 0.4 & 0.0 & 0.3 & 0.3 & 0.0 & 0.0 & 0.1 \\
\hline Business & Agriculture & 1.0 & 0.0 & 0.5 & 0.4 & 0.0 & 0.3 & 0.0 & 0.7 & 0.5 & 0.4 \\
\hline Business & Production & 2.3 & 1.4 & 1.8 & 2.3 & 4.5 & 2.9 & 3.1 & 2.0 & 1.1 & 2.2 \\
\hline Production & Professional & 1.0 & 1.0 & 1.1 & 1.7 & 1.8 & 1.8 & 0.8 & 1.5 & 1.6 & 1.3 \\
\hline Production & Business & 13.1 & 17.1 & 15.2 & 24.5 & 21.4 & 23.5 & 11.5 & 19.0 & 28.2 & 18.0 \\
\hline Production & Agriculture & 11.4 & 18.4 & 15.2 & 0.0 & 1.8 & 0.6 & 11.2 & 8.5 & 12.4 & 10.2 \\
\hline $\begin{array}{l}\text { Total } \\
\text { (N) }\end{array}$ & & $\begin{array}{l}100.0 \\
(306)\end{array}$ & $\begin{array}{l}100.0 \\
(353)\end{array}$ & $\begin{array}{c}100.0 \\
(659)\end{array}$ & $\begin{array}{l}100.0 \\
(229)\end{array}$ & $\begin{array}{r}100.0 \\
(112)\end{array}$ & $\begin{array}{c}100.0 \\
(341)\end{array}$ & $\begin{array}{c}100.0 \\
(358)\end{array}$ & $\begin{array}{r}100.0 \\
(457)\end{array}$ & $\begin{array}{r}100.0 \\
(185)\end{array}$ & $\begin{array}{l}100.0 \\
(1000)\end{array}$ \\
\hline
\end{tabular}

Source: Computed from the 1986 ILO survey data

Note: a. Return migrants, who were unemployed or inactive at the time of the ILO survey, are not included in the table.

b. Short-stayers: two years or less; medium-stayers: more than two but less than six years; long-stayers: six years or more. 
Appendix Table 8

Distribution of Return Migrants, by Direction of Occupational Movement by Level of Educational Attainment

\begin{tabular}{|c|c|c|c|c|c|}
\hline \multirow{2}{*}{$\begin{array}{l}\text { Occupation } \\
\text { before } \\
\text { Migration }\end{array}$} & \multirow{2}{*}{$\begin{array}{l}\text { Occupation } \\
\text { after } \\
\text { Migration }\end{array}$} & \multicolumn{3}{|c|}{ Level of Educational Attainment } & \multirow[b]{2}{*}{ Total } \\
\hline & & Illiterate & Pre-matriculation & $\overline{\text { Matriculation }+}$ & \\
\hline \multicolumn{6}{|l|}{ No Change in } \\
\hline Occupation & & 67.2 & 54.2 & 42.1 & 56.5 \\
\hline \multicolumn{6}{|l|}{ Change in } \\
\hline Occupation & & 32.8 & 45.8 & 57.9 & 43.5 \\
\hline Professional & Business & 0.0 & 0.7 & 7.9 & 2.0 \\
\hline Professional & Agriculture & 0.0 & 0.0 & 4.7 & 1.0 \\
\hline Professional & Production & 0.3 & 0.6 & 3.3 & 1.0 \\
\hline Agriculture & Business & 1.6 & 4.1 & 7.0 & 3.8 \\
\hline Agriculture & Production & 3.8 & 3.4 & 1.9 & 3.2 \\
\hline Business & Agriculture & 0.3 & 0.2 & 0.9 & 0.4 \\
\hline Production & Professional & 0.0 & 0.7 & 4.7 & 1.3 \\
\hline Production & Business & 12.5 & 22.1 & 19.6 & 18.0 \\
\hline Production & Agriculture & 11.9 & 11.8 & 4.2 & 10.2 \\
\hline All Other Moves & & 2.4 & 2.2 & 3.7 & 2.6 \\
\hline Total & & 100.0 & 100.0 & 100.0 & 100.0 \\
\hline$(\mathrm{N})$ & & (369) & $(417)$ & $(214)$ & (1000) \\
\hline
\end{tabular}

Source: Computed from the 1986 ILO survey.

\section{REFERENCES}

Addleton, J. S. (1992) Undermining the Centre: The Gulf Migration and Pakistan. Karachi: Oxford University Press.

Akhtar, M. R. (1997) Re-absorption of Return Migrants in Pakistan. Paper presented at the Regional Workshop on Return Migration and Long-term Economic Development in South Asia, held in Islamabad on May 26-28.

Altaf, Zafar (1983) Pakistani Entrepreneurs: Their Development, Characteristics and Attitudes. London: Croom Helm.

Alvarez, J. H. (1967) Return Migration to Puerto Rico. Berkeley: University of California.

Arif, G. M. (1991) Emigration, Skill Acquisition and Employment Choices of Return Migrants: The Experience of Pakistan. Unpublished MA Research Paper. Canberra: Australian National University.

Arif, G. M. (1995) International Contract Labour Migration and Reintegration of Return Migrants: The Experience of Pakistan. Unpublished Ph.D. thesis. Canberra: Australian National University.

Athukorala, P. (1990) International Contract Migration and Reintegration of Return Migrants: The Experience of Sri Lanka. International Migration Review 24:2 323-345. 
Ballard, R. (1987) The Political Economy of Migration: Pakistan, Britain, and the Middle East. In J. Eades (ed) Migrants, Workers, and the Social Order. 17-40. London: Tavistock Publication.

Blau, P. M., and O. D. Duncan (1967) The American Occupational Structure. New York: Willy.

Boskin, M. J. (1974) A Conditional Logit Model of Occupational Choice. The Journal of Political Economy 82:2 389-398.

Brown, R. S., M. Moon, and B. Zoloth (1980) Occupational Attainment and Segregation by Sex. Industrial and Labour Review 33: 506-517.

Campbell, R. R., D. M. Johnson, and G. Strangler (1974) Return Migration of Black People to the South. Rural Sociology 39:4 514-528.

Chaudhry, M. I. (1980) Pakistani Society: A Sociological Perspective. Lahore: Aziz Publishers.

Chaudhry, M. G., and G. M. Chaudhry (1992) Trend of Rural Employment and Wages in Pakistan. The Pakistan Development Review 31:4 803-815.

Gilani, I. (1986) Pakistan. In I. M. Abella and Y. Atal (eds) Middle East Interlude: Asian Workers Abroad. 109-174. Bangkok: UNESCO Regional Office.

Gilani, I., F. Khan, and M. Iqbal (1981) Labour Migration from Pakistan to the Middle East and Its Impact on the Domestic Economy. Islamabad: Pakistan Institute of Development Economics. (Research Report No. 126.)

Gitmez, A. S. (1984) Geographical and Occupational Re-integration of Returning Turkish Workers. In Daniel Kubat (ed) The Politics of Return: International Return Migration in Europe. 113-114. New York: Centre for Migration Studies.

Gill, A. M. (1989) The Role of Discrimination in Determining Occupational Structure. Industrial \& Labour Relations Review 42:4 610-623.

Gmelch, G. (1987) Work, Innovations, and Investment: The Impact of Return Migrants in Barbados. Human Organisation 46:2 131-140.

Pakistan, Government of (1984) The 1981 Census Report of Pakistan. Islamabad: Population Census Organisation.

Pakistan, Government of (1988) Seventh Five-Year Plan 1988-1993 and Perspective Plan 1988-2003. Islamabad: Planning Commission.

Pakistan, Government of (1989) Report of the National Manpower Commission. (3rd edition.) Islamabad: Ministry of Labour and Manpower and Overseas Pakistanis.

Pakistan, Government of (1990) Pakistan Statistical Year Book 1990. Islamabad: Federal Bureau of Statistics.

Pakistan, Government of (1994) Eighth Five-Year Plan 1993-1998, Islamabad: Planning Commission.

Greenhalgh, C. A., and M. B. Stewart (1985) The Occupational Status and Mobility of British Men and Women. Oxford Economic Papers 37:1 40-71.

Hear, N. V. (1992) Consequences of the Forced Mass Repatriation of Migrant Communities: Recent Cases from West Africa and the Middle East. Geneva: 
United Nations Research Institute for Social Development. (Discussion Paper 38.)

ILO/ARTEP (1987) Impact of Out and Return Migration on Domestic Employment in Pakistan. Volume II, Re-absorption of Return Migrants in the Domestic Economy. New Delhi: ILO/ARTEP.

ILO/ARTEP (1987a) Impact of Out and Return Migration on Domestic Employment in Pakistan. Volume V, Survey of Return Migrants Sample Design and Field Work. New Delhi: ILO/ARTEP.

Kazi, S. (1989) Domestic Impact of Overseas Migration: Pakistan. In R. Amjad (ed) To the Gulf and Back: Studies on the Economic Impact of Asian Labour Migration. New Delhi: ILO/ARTEP.

Khan, F. M. (1991) Migrant Workers to the Arab World: The Experience of Pakistan. In G. Gunatilleke (ed) Migration to the Arab World: The Experience of Returning Migrants. 195-237. Tokyo: United Nations University Press.

King, R., J. Mortimer, and A. Strachan (1984) Return Migration and Tertiary Development: A Calabrian Case-study. Anthropological Quarterly 57:3 12-124.

Kossoudji, S. A., and D. A. Cobb-Clark (1996) Finding Good Opportunities within Unauthorised Markets: U.S. Occupational Mobility for Male Latino Workers. International Migration Review 30:4 901-924.

Lefebvre, A. (1990) International Labour Migration from Two Pakistani Villages with Different Forms of Agriculture. The Pakistan Development Review 29:1 59-90.

Mahmood, R. A. (1991) Bangladeshi Returned Migrants from the Middle East: Process, Achievement, and Adjustment. In G. Gunatilleke (ed) Migration to the Arab World: Experience of Returning Migrants. 238-289. Tokyo: United Nations University Press.

Mayhew, K., and B. Rosewell (1981) Occupational Mobility in Britain. Oxford Bulletin of Economics and Statistics 43:3 225-256.

Mullan, B. P. (1988) Social Mobility among Migrants between Mexico and the U.S. and within the U.S. Labour Market. International Migration 26:1 71-93.

Nair, P. R. G. (1991) Asian Migration to the Arab World: Kerala (India). In G. Gunatilleke (ed) Migration to the Arab World: Experience of Returning Migrants. 19-55. Tokyo: United Nations University Press.

Paine, S. (1974) Exporting Workers: The Turkish Case. London: Cambridge University Press.

Seok, H. (1991) Korean Migrant Workers to the Middle East. In G. Gunatilleke (ed) Migration to the Arab World: Experience of Returning Migrants. 56-102. Tokyo: United Nations University Press.

Shaw, K. L. (1984) The Concept of Occupational Investment. The Journal of Human Resources 19:3 319-340. 
Smart, J. E., V. A. Teodosio, and C. J. Jimenez (1986) Skills and Earnings: Issues in the Developmental Impact on the Philippines of Labour Export to the Middle East. In F. Arnold and N. M. Shah (eds) Asian Migration: Pipeline to the Middle East. 101-124. London: Westview.

Stahl, C. W. (1982) Labour Migration and Economic Development. International Migration Review 16:4 869-900.

Stahl, C. W., and F. Azam (1990) Counting Pakistanis in the Middle East: Problems and Policy Implications. Asian and Pacific Population Forum 4:2 1-10, 24-28.

Stahl, C. W., and R. T. Appleyard (1992) International Manpower Flows: An Overview. Asian and Pacific Migration Journal 1:3\&4 417-476.

Stauth, G. (1987) Remigration and Social Change-Prospects for the Migrant Worker Sending Countries of the Middle East. The Pakistan Development Review 26:4 735-744.

Thomas-Hope, E. M., and R. D. Nutter (1989) Occupation and Status in the Ideology of Caribbean Return Migration. In R. T. Appleyard (ed) The Impact of International Migration on Developing Countries. 287-300. Paris: OECD.

Weiss, Y. (1968) Allocation of Time and Occupational Choice. Unpublished Ph.D. Thesis. Stanford: Stanford University.

Wilson, F. D. (1985) Migration and Occupational Mobility: A Research Note. International Migration Review 19:2 278-292. 